\title{
COMMUNITY ECOLOGY OF METAZOAN PARASITES OF THE LATER JUVENILE COMMON SNOOK Centropomus undecimalis (OSTEICHTHYES: CENTROPOMIDAE) FROM THE COASTAL ZONE OF THE STATE OF RIO DE JANEIRO, BRAZIL
}

\author{
TAVARES, L. E. R. and LUQUE, J. L. \\ Curso de Pós-graduação em Ciências Veterinárias, Departamento de Parasitologia Animal, Universidade Federal \\ Rural do Rio de Janeiro, C.P. 74508, CEP 23851-970, Seropédica, RJ, Brazil \\ Correspondence to: José Luis Luque, Departamento de Parasitologia Animal, Universidade Federal Rural do \\ Rio de Janeiro, C.P. 74508, CEP 23851-970, Seropédica, RJ, Brazil, e-mail: jlluque@ufrrj.br \\ Received December 16, 2002 - Accepted April 30, 2003 - Distributed August 31, 2004
}

\begin{abstract}
Between April and December 2000, seventy-nine specimens of Centropomus undecimalis from Angra dos Reis, coastal zone of the State of Rio de Janeiro ( $23^{\circ} 01^{\prime} \mathrm{S}, 44^{\circ} 19^{\prime} \mathrm{W}$ ), Brazil, were necropsied to study their infracommunities of metazoan parasites. Nine species of metazoan parasites were collected: 1 digenean, 1 monogenean, 1 acantocephalan, 1 nematode, 4 copepods, and 1 isopod, and 96.2\% of the fishes were parasitized by one or more metazoan, with mean of $85.3 \pm 122.9$ parasite/fish. The digenean Acanthocollaritrema umbilicatum Travassos, Freitas \& Bührnheim represented the majority of the parasites specimens collected, totaling, $94.7 \%$. This species was the most abundant, prevalent, and dominant, showing positive correlation with the host's total body length and parasite abundance. The copepod species Acantholochus unisagittatus Tavares \& Luque presented differences in abundance in relation to sex of host. The mean diversity in the infracommunities of $C$. undecimalis was $H=$ $0.095 \pm 0.116$, with no correlation with the host's total body length but correlated with the host's sex. No pair of parasite species showed positive or negative association or covariation. The dominance of digenean A. umbilicatum in the later juvenile common snook parasite community could be related with the predatory food habits of common snook and an apparent feeding transition period which might occasion great exposure to infective forms.
\end{abstract}

Key words: parasite ecology, community structure, marine fish, Centropomidae, Centropomus undecimalis, Brazil.

\section{RESUMO}

\section{Ecologia da comunidade de metazoários parasitos de Centropomus undecimalis do} litoral do Estado do Rio de Janeiro, Brasil

Entre abril e dezembro de 2000, 79 espécimes de $C$. undecimalis, provenientes de Angra dos Reis,

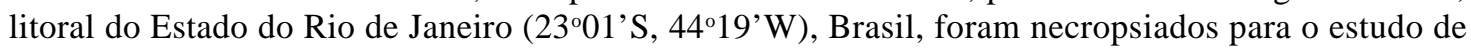
suas infracomunidades de metazoários parasitos. Foram coletadas nove espécies de metazoários parasitos: 1 digenético, 1 monogenético, 1 acantocéfalo, 1 nematóide, 4 copépodes e 1 isópode; e 96,2\% dos peixes estavam parasitados por um ou mais metazoários parasitos, com média de $85,3 \pm 122,9$ parasitos/peixe. O digenético Acanthocollaritrema umbilicatum Travassos, Freitas \& Bührnheim foi o táxon maioritário, representando $94,7 \%$ do total de parasitos coletados. Esta espécie foi a mais abundante, prevalente e dominante, apresentando correlação positiva entre o comprimento total dos hospedeiros e a abundância parasitária. O copépode Acantholochus unisagittatus Tavares \& Luque apresentou diferenças em sua abundância em relação ao sexo dos hospedeiros. A diversidade média das infracomunidades de $C$. undecimalis foi de $H=0,095 \pm 0,116$ sem correlação com o comprimento 
total dos hospedeiros e com diferenças em relação ao sexo dos hospedeiros. Nenhum par de espécies demonstrou associação e covariação positiva ou negativa. A dominância do digenético A. umbilicatum na comunidade parasitária dos robalos jovens pode estar relacionada ao hábito predador e ao aparente período de transição alimentar, que pode levar a uma grande exposição às formas infectantes.

Palavras-chave: ecologia parasitária, estrutura comunitária, peixes marinhos, Centropomidae, Centropomus undecimalis, Brasil.

\section{INTRODUCTION}

The common snook, Centropomus undecimalis (Bloch, 1792) is a demersal species that spends much of its life in estuaries, but migrates to ocean inlets or just offshore to spawn (Tucker \& Campbell, 1988). This is a euryhaline and diadromous fish, with known distribution from Pamlico Sound, North Carolina, USA, southward to Rio de Janeiro, Brazil (Rivas, 1986). Centropomus undecimalis is predaceous and occupies high levels in the trophic web (Figueiredo $\&$ Menezes, 1980). Centropomid fishes are commercially important and widely used in aquaculture as a food fish and also as recreational fish (VasconcelosFilho \& Galiza, 1980; Bórquez \& Cerqueira, 1998; Kennedy et al., 1998; Tolley \& Peebles, 1998).

Some recently published taxonomic papers on the parasites of Centropomus species from Brazil are: Wallet \& Kohn (1987); Rodrigues et al. (1990); Robaldo \& Padovan (1998) on digenean; BravoHollis (1986) and Kritsky et al. (2001) on monogeneans; and Tavares \& Luque (2003) on copepods.

Studies on quantitative aspects of the parasites of $C$. undecimalis from the Brazilian coastal zone were restricted to the digenean A. umbilicatum (Tavares \& Luque, 2001a) and to the copepod Caligus praetextus Bere, 1936 (Tavares \& Luque, 2001b). Studies on ecological aspects of parasite infracommunities of $C$. undecimalis are unknown.

In this report, we analyzed at the component and infra-community levels the metazoan parasite community of $C$. undecimalis from the coastal zone of the State of Rio de Janeiro.

\section{MATERIALS AND METHODS}

From April to December 2000, 79 specimens of $C$. undecimalis were examined from Angra dos Reis, coastal zone of the State of Rio de Janeiro,

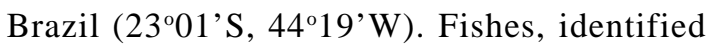
according to Rivas (1986), measured $18.5-47.0 \mathrm{~cm}$ $($ mean $=35.2 \pm 3.4 \mathrm{~cm})$ in total length. The average total length of male $(35.8 \pm 4.1 \mathrm{~cm}, n=39)$ and female $(35.3 \pm 1.9 \mathrm{~cm}, n=27)$ fishes in the study sample were not significantly different $(t=0.569$, $p=0.575$ ); thirteen specimens measuring $33.7 \pm$ $5.1 \mathrm{~cm}$ were not differentiated as male or female and not included in this analysis. The term "later juvenile common snook" was used according to Peters et al. (1998) to classify the common snook specimens with body size similar to the sample studied in the present report.

The analysis included only parasite species with prevalence higher than 10\% (Bush et al., 1990). The quotient between variance and mean of parasite abundance (index of dispersion) was used to determine distribution patterns, and its significance was tested using $\mathrm{d}$ statistical test. The dominance frequency and the relative dominance (number of specimens of one species/total number of specimens of all species in the infracommunity) of each parasite species were calculated according to Rohde $e t$ al. (1995). Spearman's rank correlation coefficient $r$ was calculated to determine possible correlations between total length of hosts and abundance of parasites. Pearson's correlation coefficient $r$ was used as an indication of the relationship between the host's total length and the prevalence of parasites, with previous arcsine transformation of the prevalence data (Zar, 1999) and partition of host samples into four $5 \mathrm{~cm}$ length intervals. The effect of host sex on abundance and prevalence of parasites was tested using the $Z_{c}$ normal approximation to the MannWhitney test and the Fisher exact test, respectively. Parasite species diversity was calculated using the Brillouin index $(H)$, because each fish analyzed corresponded to a fully censused community (Zar, 1999). The probable variation of diversity in relation to host sex (Mann-Whitney test) and to host total length (Spearman's rank correlation coefficient) was tested. For each infracommunity, evenness (Brillouinbased evenness index) was calculated. The possible interspecific association between concurrent species was analyzed using the chi-square test. Possible 
covariation among the abundance of concurrent species was analyzed using the Spearman rank correlation coefficient. Ecological terminology follows Bush et al. (1997). Statistical significance level was evaluated at $p \leq 0.05$.

Voucher specimens from representative species of helminths were deposited in the Coleção Helmintológica do Instituto Oswaldo Cruz (CHIOC), Rio de Janeiro, Brazil; copepods and isopods were deposited in the Coleção de Crustacea do Museu Nacional (MNRJ), Rio de Janeiro, Brazil.

\section{RESULTS}

\section{Component community}

Nine species of metazoan parasites were collected (Table 1). The digenean A. umbilicatum, the most abundant and dominant species, accounted for $94.7 \%$ of total parasites collected and showed the highest values of mean relative dominance and frequency of dominance (Table 2). All parasites of $C$. undecimalis had the typical aggregated pattern of distribution observed in many parasite systems. Acanthocollaritrema umbilicatum showed the highest values of dispersion indices (Table 3 ). Abundance of $A$. umbilicatum was positively correlated with host total length, although prevalence of no specieswassignificantly correlated with host's total length (Table 4). The mean abundance and prevalence of A. unisagittatus were significant higher in the male $(95.7$ and $81.5 \%)$ than in the female $(56.3$ and $76.9 \%)$ hosts $\left(Z_{c}=-2.15, p=\right.$ $0.03 ; F=0.05)$.

\section{Infracommunities}

Ninety-six percent of common snooks were parasitized by at least one parasite species. A total of 6,741 individual parasites was collected, with mean of $85.3 \pm 122.9$ parasite/fish. The value of dispersion indices for the total individual parasites was 75.573. Relationships between total parasite abundance and total body length of fish were observed $\left(r_{s}=0.233\right.$, $p=0.03$ ). Mean parasite species richness $1.9 \pm 1$ (1-4) was not correlated with total body length of fish $\left(r_{s}=0.063, p=0.581\right)$. Twenty-eight hosts (36\%) showed infection with one parasite species and 31 (39\%), 12 (15\%), and 5 (6\%) had multiple infections with 2, 3, and 4 species, respectively. Mean parasite species diversity $(H)$ was $0.095 \pm 0.116$ and maximum diversity was 0.391 . The Brillouin-based evenness index $(J)$ had a mean of $0.295 \pm 0.358$. Parasite diver- sity was not correlated to host total length $\left(r_{s}=-0.01\right.$, $p=0.93)$ and significant differences $(t=-2.35, p=$ 0.03 ) in parasite diversity were observed between male $(H=0.127 \pm 0.126)$ and female common snooks $(H=0.077 \pm 0.105)$.

Only one group, ectoparasites (copepods), was used to determine possible interspecific associations. Adult endoparasites and larval stages were not included in this analysis because only one species of each group showed prevalence higher than $10 \%$ ( $A$. umbilicatum as an adult and Contracaecum sp. in the larval stage). The copepod species pair $A$. unisagittatus and $C$. praetextus did not share significant association and covariation $\left(\chi^{2}=2.47, p=\right.$ $\left.0.116 ; r_{s}=0.130, p=0.253\right)$.

\section{DISCUSSION}

We detected some patterns in the structure and composition of the community of metazoan parasites of $C$. undecimalis from Brazil: (1) endoparasite dominance; (2) correlation of parasite abundance with host size; and (3) lack of parasite interpecific relationships.

The dominance of digenean endoparasites has been described for several parasite communities of marine fishes from the coastal zone of southeastern Brazil (Luque et al., 1996; Takemoto et al., 1996; Knoff et al., 1997; Luque \& Chaves, 1999; Silva et al., 2000; Luque \& Alves, 2001). Feeding habits and broad diet spectrum of demersal fishes, which bring them in contact with several potential intermediate hosts of marine acanthocephalan, digenean, and nematodes, might increase the presence of endoparasites in these fishes (Alves \& Luque, 2001). The later juvenile Centropomus undecimalis shows predatory habits and an apparent feeding transition period (Vasconcelos-Filho \& Galiza, 1980; Teixeira, 1997), thus, great exposure to infective stages of parasites trophically transmitted is possible.

According Sasal et al. (1999), the diet of the host species is the main factor affecting parasite community structure, specially for digenean trematodes that are transmitted to their final host through a predator-prey relationship. These authors proposed that hosts with a more diversified diet should encounter more intermediate host species and, consequently, harbor more parasite species. Despite parasite abundance and prevalence shown in the common snook, in the present report parasite species richness was lower than expected. Many authors have 
reported diversified predatory feeding habits for this fish species (Harrington \& Harrington, 1961; Vasconcelos-Filho \& Galiza, 1980; Lau \& Shafland, 1982; Gilmore et al., 1983; McMichael et al., 1989; Teixeira, 1997; Peters et al., 1998). However, as reported by Teixeira (1997) and Peters et al. (1998), although as nursery grounds estuaries represent the most important habitat for common snook, because they are near urban areas these ecosystems suffer great anthropic pressure resulting from organic and industrial discharges. This leads to eutrophication, followed by increased biological oxygen demand which subsequently produces mortalities of many forage species (Khan \& Thulin, 1991).

TABLE 1

Prevalence, intensity, mean intensity, mean abundance, and site of infection of the metazoan parasites of Centropomus undecimalis from the coastal zone of the State of Rio de Janeiro, Brazil.

\begin{tabular}{|c|c|c|c|c|c|}
\hline Parasites & $\begin{array}{c}\text { Prevalence } \\
(\%)\end{array}$ & Intensity & $\begin{array}{c}\text { Mean } \\
\text { intensity }\end{array}$ & $\begin{array}{c}\text { Mean } \\
\text { abundance }\end{array}$ & $\begin{array}{c}\text { Site of } \\
\text { infection }\end{array}$ \\
\hline \multicolumn{6}{|l|}{ DIGENEA } \\
\hline $\begin{array}{l}\text { Acanthocollaritrema umbilicatum } \\
(\text { CHIOC } 34702 \mathrm{a}, \mathrm{b})\end{array}$ & 83.5 & $1-618$ & $96.7 \pm 129.1$ & $80.8 \pm 123.2$ & Intestine \\
\hline \multicolumn{6}{|l|}{ MONOGENEA } \\
\hline $\begin{array}{l}\text { Rhabdosynochus hargisi } \\
\text { (CHIOC 34708) }\end{array}$ & 8.9 & $1-8$ & $2.9 \pm 2.7$ & $0.3 \pm 1.1$ & Gills \\
\hline \multicolumn{6}{|l|}{ ACANTOCEPHALA } \\
\hline $\begin{array}{l}\text { Corynosoma sp. (cystacanth) } \\
\text { (CHIOC 34710) }\end{array}$ & 2.5 & --- & 1 & $<0.1$ & Intestine \\
\hline \multicolumn{6}{|l|}{ NEMATODA } \\
\hline $\begin{array}{l}\text { Contracaecum sp. (larval) } \\
\text { (CHIOC } 34670)\end{array}$ & 12.7 & $1-8$ & $3.8 \pm 2.9$ & $0.5 \pm 1.6$ & Mesenteries \\
\hline \multicolumn{6}{|l|}{ COPEPODA } \\
\hline $\begin{array}{l}\text { Acantholochus unisagittatus } \\
\text { (MNRJ 15425) }\end{array}$ & 53.2 & $1-19$ & $6.2 \pm 4.9$ & $3.3 \pm 4.7$ & Gills \\
\hline $\begin{array}{l}\text { Caligus praetextus } \\
(\mathrm{MNRJ} 15341)\end{array}$ & 11.4 & $1-5$ & $1.8 \pm 1.4$ & $0.2 \pm 0.7$ & Body surface \\
\hline $\begin{array}{l}\text { Ergasilus sp. } \\
\text { (MNRJ 15426) }\end{array}$ & 3.8 & $3-4$ & $3.7 \pm 0.6$ & $0.1 \pm 0.7$ & Gills \\
\hline $\begin{array}{l}\text { Lernanthropus gisleri } \\
\text { (MNRJ 15342) }\end{array}$ & 3.8 & --- & 1 & $<0.1$ & Gills \\
\hline \multicolumn{6}{|l|}{ ISOPODA } \\
\hline $\begin{array}{l}\text { Cymothoid not identified } \\
\text { (MNRJ 15427) }\end{array}$ & 5.1 & $1-2$ & $1.3 \pm 0.5$ & $<0.1$ & Body surface \\
\hline
\end{tabular}

TABLE 2

Frequency of dominance and mean relative dominance of the metazoan parasites of Centropomus undecimalis from the coastal zone of the State of Rio de Janeiro, Brazil.

\begin{tabular}{|l|c|c|c|}
\hline \multicolumn{1}{|c|}{ Parasites } & $\begin{array}{c}\text { Frequency of } \\
\text { dominance }\end{array}$ & $\begin{array}{c}\text { Frequency of dominance } \\
\text { shared with one or more } \\
\text { species }\end{array}$ & $\begin{array}{c}\text { Mean relative } \\
\text { dominance }\end{array}$ \\
\hline Acanthocollaritrema umbilicatum & 60 & 2 & $0.708 \pm 0.381$ \\
\hline Contracaecum sp. (larval) & 2 & 1 & $0.027 \pm 0.118$ \\
\hline Acantholochus unisagittatus & 11 & 6 & $0.171 \pm 0.278$ \\
\hline Caligus praetextus & 1 & 2 & $0.023 \pm 0.120$ \\
\hline
\end{tabular}


TABLE 3

Dispersion index (DI) and $d$ test of the metazoan parasites of Centropomus undecimalis from the coastal zone of the State of Rio de Janeiro, Brazil.

\begin{tabular}{|l|c|c|}
\hline \multicolumn{1}{|c|}{ Parasites } & DI & d \\
\hline Acanthocollaritrema umbilicatum & 187.9 & 158.8 \\
\hline Contracaecum sp. (larval) & 5.33 & 36.5 \\
\hline Acantholochus unisagittatus & 6.7 & 19.9 \\
\hline Caligus praetextus & 2.6 & 7.7 \\
\hline
\end{tabular}

TABLE 4

Spearman's rank correlation coefficient $\left(r_{s}\right)$ and Pearson's correlation coefficient $(r)$ values used to evaluate possible relationships among the total length of Centropomus undecimalis, abundance and prevalence of the components of its parasite community in the coastal zone of the State of Rio de Janeiro, Brazil.

\begin{tabular}{|l|c|c|c|c|}
\hline \multicolumn{1}{|c|}{ Parasites } & $\boldsymbol{r}_{\boldsymbol{s}}$ & $\boldsymbol{p}$ & $\boldsymbol{r}$ & $\boldsymbol{p}$ \\
\hline Acanthocollaritrema umbilicatum & 0.223 & $0.048^{*}$ & 0.780 & 0.117 \\
\hline Contracaecum sp. (larval) & 0.029 & 0.799 & 0.202 & 0.550 \\
\hline Acantholochus unisagittatus & $<0.01$ & 0.998 & 0.302 & 0.450 \\
\hline Caligus praetextus & 0.062 & 0.586 & 0.541 & 0.264 \\
\hline
\end{tabular}

*: significant values; $p$ : significance level.

Also, the schooling behavior related for juvenile and adult common snook (Peters et al., 1998) might favor direct ectoparasite transmission. Some ectoparasite species showed prevalence higher than $10 \%$ on C. undecimalis from Rio de Janeiro. In mariculture activities with high fish population density, ectoparasite prevalence and abundance increase is possible (Euzet \& Raibaut, 1985). The ectoparasite fauna of common snook from Rio de Janeiro is composed by species with high pathogenic potential such as caligid and ergasilid copepods. We emphasize sea lice occurrence since Caligus species are responsible for great economic losses in world fish farming Caligus praetextus (Tavares \& Luque, 2001b).

The correlation among total length of $C$. undecimalis and abundance of $A$. umbilicatum, might originate in accumulative infection. Sasal et al. (1999) observed that large fish are supposed to eat more and, therefore, ingest more intermediate hosts. This is a pattern previously found in other marine fishes from Rio de Janeiro (Luque et al., 1996; Knoff et al., 1997; Luque \& Chaves, 1999; Luque \& Alves, 2001; Alves \& Luque, 2001; Tavares et al., 2001). According to Polyanski (1961), quantitative and qualitative changes in parasitism are expected with fish growth. In the case of digeneans, this relationship is strongly influenced by changes in feeding habits of the fish correlated with age (Saad-Fares \& Combes, 1992). Juvenile common snook have a preliminary pelagic stage followed by a longer demersal stage (Peters et al., 1998) and show an apparent feeding transition period associated to this ontogenetic change in habitat. Early juvenile common snook feed mainly on copepods, other microcrustaceans, and insect larvae, while later juvenile and adult common snook feed on a wider range of food items, specially finfishes and shrimps (Harrington \& Harrington, 1961; Vasconcelos-Filho \& Galiza, 1980; Teixeira, 1997), which can be intermediate hosts of digenean parasites in marine fishes.

The correlation of the sex of $C$. undecimalis with abundance and prevalence of copepod $A$. unisagittatus was surprising because biological differences in male and female common snook are unclear. Snooks are protandrous and size at maturity is somewhat confusing (Peters et al., 1998). Moreover, Poulin (1996) stated that high testosterone levels can cause immunosuppression in males and could lead in some cases to males suffering more from parasites than do females, although many parasite surveys have reported no significant differences in infection abun- 
dance and prevalence between female and male hosts. Quantitative relationships of the sex of the host with infection levels of some components of the parasite communities were also detected in other marine fishes from Rio de Janeiro (Luque et al., 1996; Knoff et al., 1997; Alves \& Luque, 2001) and may suggest ecological and behavioral differences between female and male hosts.

The lack of parasite species associated pairs shown in C. undecimalis is in agreement with the data obtained on other marine fishes, where the presence of a low number of associated species is a common pattern (Rohde et al., 1995). However, these data from quantitative associations between parasite species could be used with caution to explain the parasite community structure. According to Rohde et al. (1995) and Poulin (2001), interspecific relationships can only be considered valid when tested under experimental conditions. These results reinforce the postulate of Rohde et al. (1995) according to which the parasite community structure in marine fishes constitutes a confused and unsaturated species complex, unlike the interactive patterns related for other host groups.

Acknowledgements - J. L. Luque was supported by a Research fellowship from CNPq (Conselho Nacional de Pesquisa e Desenvolvimento Tecnológico). L. E. R. Tavares was supported by sudent fellowships from CAPES (Coordenação de Aperfeiçoamento do Pessoal de Ensino Superior).

\section{REFERENCES}

ALVES, D. R. \& LUQUE, J. L., 2001, Community ecology of the metazoan parasites of white croaker, Micropogonias furnieri (Osteichthyes: Sciaenidae), from the coastal zone of the State of Rio de Janeiro, Brazil. Mem. Inst. Oswaldo Cruz, 96: 145-153.

BÓRQUEZ, A. \& CERQUEIRA, V. R., 1998, Feeding behavior in juvenile snook, Centropomus undecimalis. I - Individual effect of some chemical substances. Aquaculture, 169: 2535 .

BRAVO-HOLLIS, M., 1986, Sobre una subfamilia, género y especies nuevos de un microcotilido de las branquias de un pez marino Centropomus paralellus, de Brasil. An. Inst. Biol. Univ. Nal. Autón. Méx., Ser. Zool., 56: 671-682.

BUSH, A. O., AHO, J. M. \& KENNEDY, C. R., 1990, Ecological versus phylogenetic determinants of helminth parasite community richness. Evol. Ecol., 4: 1-20.

BUSH, A. O., LAFFERTY, K. D., LOTZ, J. M. \& SHOSTAK, A. W., 1997, Parasitology meets ecology on its own terms: Margolis et al. Revisited. J. Parasitol., 83: 575-583.
EUZET, L. \& RAIBAUT, A., 1985, Les maladies parasitaires en pisciculture marine. Symbioses, 18: 51-68.

FIGUEIREDO, J. L. \& MENEZES, N., 1980, Manual de peixes marinhos do Sudeste do Brasil III - Teleostei 2. Museu de Zoologia, Universidade de São Paulo, São Paulo, 90p.

GILMORE, R. G., DONOHOE, C. J. \& COOKE, D. W., 1983, Observations on the distribution and biology of east-central Florida populations of the common snook, Centropomus undecimalis (Bloch). Fla. Sci., 46: 313-336.

HARRINGTON Jr., R. W. \& HARRINGTON, E. S., 1961, Food selection among fishes invading a high subtropical salt marsh: from onset of flooding through the progress of a mosquito brood. Ecology, 42: 646-666.

KHAN, L. \& THULIN, B., 1991, Influence of pollution on parasites of Aquatic animals. Adv. Parasitol., 30: 201-238.

KENNEDY, S. B., TUCKER, J. W., NEIDIG, C. L., VERMEER, G. K., COOPER, V. R., JARREL, J. L. \& SENNETT, D. G., 1998, Bacterial management strategies for stock enhancement of warm water marine fish: A case study with common snook Centropomus undecimalis. Bull. Mar. Sci., 62: 573-588.

KNOFF, M., LUQUE, J. L. \& AMATO, J. F. R., 1997, Community ecology of the metazoan parasites of grey mullets, Mugil platanus (Osteichthyes: Mugilidae) from the littoral of the State of Rio de Janeiro, Brazil. Rev. Bras. Biol., 57: 441-454.

KRITSKY, D. C., BOEGER, W. A. \& ROBALDO, R. B., 2001, Neotropical Monogenoidea. 38. Revision of Rhabdisynochus Mizelle and Blatz, 1941 (Polyonchoinea: Dactylogyridea: Diplectanidae), with descriptions of two new species from Brazil. Comp. Parasitol., 68: 66-75.

LAU, S. R. \& SHAFLAND, P. L., 1982, Larval development of snook, Centropomus undecimalis (Pisces, Centropomidae). Copeia, 3: 618-627.

LUQUE, J. L., AMATO, J. F. R. \& TAKEMOTO, R. M., 1996, Comparative analysis of the communities of metazoan parasites of Orthopristis ruber and Haemulon steindachneri (Osteichthyes: Haemulidae) from the southeastern Brazilian littoral: I. structure and influence of the size and sex of hosts. Rev. Bras. Biol., 56: 279-292.

LUQUE, J. L. \& CHAVES, N. D., 1999, Ecologia da comunidade de metazoários parasitos da anchova Pomatomus saltator (Linnaeus) (Osteichthyes, Pomatomidae) do litoral do Estado do Rio de Janeiro, Brasil. Rev. Bras. Zool. 16: 711-723.

LUQUE, J. L. \& ALVES, D. R., 2001, Ecologia das comunidades de metazoários parasitos, do xaréu, Caranx hippos (Linnaeus) e do xerelete, Caranx latus Agassiz (Osteichthyes, Carangidae) do litoral do Estado do Rio de Janeiro, Brasil. Rev. Bras. Zool., 18: 399-410.

McMICHAEL, R. H., PETERS Jr., K. M. \& PARSONS, G. R., 1989, Early life history of the snook, Centropomus undecimalis, in Tampa Bay, Florida. North. Gulf. Sci., 10: 113-125. 
PETERS, K. M., MATHESON, R. E. \& TAYLOR, R. C., 1998 Reproduction and early life history of common snook, Centropomus undecimalis (Bloch), in Florida. Bull. Mar. Sci., 62: 509-529.

POLYANSKI, Y. I., 1961, Ecology of parasites of marine fishes, pp. 1-47. In: A. V. Dogiel, G. K. Petrushevski \& Y. I. Polyanski (eds.), Parasitology of fishes. Oliver and Boyd, London.

POULIN, R., 1996, Sexual inequalities in helminth infections: a cost of being male. Am. Nat., 147: 287-295.

POULIN, R., 2001, Interactions between species and the structure of helminth communities. Parasitol., 122: S3-S11.

RIVAS, L. R., 1986, Systematic review of the perciform fishes of the genus Centropomus. Copeia, 3: 579-611.

ROBALDO, R. B. \& PADOVAN, I. P., 1998, Acanthocollaritrema umbilicatum Travassos, Freitas \& Bürnheim, 1965 (Digenea: Acanthocollaritrematidae) from the common snook, Centropomus undecimalis, from Itamaracá, State of Pernambuco, Brazil. Mem. Inst. Oswaldo Cruz, 93: 303-307.

RODRIGUES, H. O., RODRIGUES, S. S. \& FARIA, Z., 1990 Contribution to the knowledge of the helminthological fauna of vertebrates of Maricá, Rio de Janeiro State, Brazil. Mem. Inst. Oswaldo Cruz, 85: 115-116.

ROHDE, K., HAYWARD, C. \& HEAP, M., 1995, Aspects of the ecology of metazoan ectoparasites of marine fishes. Int. Jour. Parasitol., 25: 945-970.

SASAL, P., NIQUIL, N. \& BARTOLI, P., 1999, Community structure of digenean parasites of sparid and labrid fishes of the Mediterranean Sea: a new approach. Parasitol., 119: 635-648.

SAAD-FARES, A. \& COMBES, C., 1992, Abundance/host size relationships in a fish trematode community. J. Helminthol., 66: 187-192.

SILVA, L. O., LUQUE, J. L., ALVES, D. R. \& PARAGUASSÚ, A. R., 2000, Ecologia da comunidade de metazoários parasitos do peixe-espada Trichiurus lepturus Linnaeus (Osteichthyes, Trichiuridae) do litoral do Estado do Rio de Janeiro, Brasil. Rev. Bras. Zooc., 2: 115-133.

TAKEMOTO, R. M., AMATO, J. F. R. \& LUQUE, J. L., 1996 Comparative analysis of the metazoan parasite communities of leatherjackets, Oligoplites palometa, $O$. saurus and $O$. saliens (Osteichthyes: Carangidae) from Sepetiba Bay, Rio de Janeiro, Brazil. Rev. Bras. Biol., 56: 639-650.
TAVARES, L. E. R. \& LUQUE, J. L., 2001a, Aspectos quantitativos das infrapopulações de Acanthocollaritrema umbilicatum Travassos, Freitas \& Bührnheim, 1965 (Digenea: Acanthocollaritrematidae) parasitos do robalo Centropomus undecimalis (Bloch, 1792) (Osteichthyes: Centropomidae) no litoral do Estado do Rio de Janeiro, Brasil. Rev. Bras. Zooc., 3: 231-238.

TAVARES, L. E. R. \& LUQUE, J. L., 2001b, Aspectos quantitativos das infrapopulações de Caligus praetextus Bere, 1936 (Copepoda: Caligidae) parasitos do robalo Centropomus undecimalis (Bloch, 1792) (Osteichthyes: Centropomidae) no litoral do Estado do Rio de Janeiro, Brasil. Rev. Bras. Zooc., 3: 253-258.

TAVARES, L. E. R. \& LUQUE, J. L., 2003, A new species of Acantholochus (Copepoda: Bomolochidae) parasitic on Centropomus undecimalis (Osteichthyes: Centropomidae) from the coastal zone of the State of Rio de Janeiro, Brazil. Mem. Inst. Oswaldo Cruz, 98: 241-245.

TAVARES, L. E. R., LUQUE, J. L. \& NETO, S. L. B., 2001, Ecologia da comunidade de metazoários parasitos do olhode-cão Priacanthus arenatus (Cuvier, 1829) (Osteichthyes: Priacanthidae) do litoral do Estado do Rio de Janeiro, Brasil. Rev. Bras. Zooc., 3: 45-59.

TEIXEIRA, R. L., 1997, Distribution and feeding habits of the young common snook, Centropomus undecimalis (Pisces: Centropomidae), in the shallow waters of a tropical Brazilian estuary. Bol. Mus. Biol. Mello Leitão, 6: 35-46.

TOLLEY, S. G. \& PEEBLES, E. B., 1998, Decay of diel patterns of swimming activity in juvenile common snook (Centropomus undecimalis) maintained in captivity. Bull. Mar. Sci., 62: 275-283.

TUCKER Jr., J. W. \& CAMPBELL, S. W., 1988, Spawning season of common snook along the east central Florida coast. Fla. Sci., 51: 1-6.

VASCONCELOS-FILHO, A. L. \& GALIZA, E. M. B., 1980, Hábitos alimentares dos peixes centropomídeos cultivados em viveiros da região de Itamaracá, Pernambuco. Rev. Nord. Biol., 3: 111-122.

WALLET, M. \& KOHN, A., 1987, Trematodes parasites de poisson marins du littoral de Rio de Janeiro, Brésil. Mem. Inst. Oswaldo Cruz, 82: 21-27.

ZAR, J. H., 1999, Biostatistical analysis. New Jersey, PrenticeHall Inc., 663p. 